\title{
Beyond the Dichotomous Vote: Can Expressive Ballots Increase Ideological Congruence and Decrease Parliamentary Polarization?
}

\author{
Victor Ellenbroek ${ }^{1}$ (D), Maurits J. Meijers ${ }^{2 \star}$ (D) and André Krouwel $^{3}$ (D) \\ ${ }^{1}$ Department of Political Science, Nijmegen School of Management, Radboud University, Nijmegen, the \\ Netherlands, ${ }^{2}$ Department of Political Science, Nijmegen School of Management, Radboud University, \\ Nijmegen, the Netherlands and ${ }^{3}$ Department of Communication Science and Department of Political \\ Science, Vrije Universiteit Amsterdam, Amsterdam, the Netherlands \\ ${ }^{*}$ Corresponding author. Email: m.meijers@fm.ru.nl
}

(Received 18 March 2019; revised 19 September 2019; accepted 23 September 2019; first published online 6 November 2019)

\begin{abstract}
As scholars explore opportunities for democratic renewal, the potential of ballot structures to improve the quality of representation has been largely neglected. We argue that expressive ballots can improve the congruence of political preferences between voters and their vote choice and, subsequently, decrease parliamentary polarization. Recognizing that voters' political preferences are more complex than a dichotomous party-vote allows, we propose the 'assembly ballot', which allows voters to choose their 'ideal parliament' by distributing 150 parliamentary seats across all participating parties. To assess the consequences of the assembly ballot for ideological congruence and parliamentary composition, we conducted a survey experiment with over 16,000 respondents around the 2017 Dutch parliamentary elections in which respondents cast a vote in a mock-election using the assembly ballot or a closed-list PR ballot. Results show that ideological congruence is, on average, significantly higher for voters voting with the assembly ballot for both the left-right dimension and the cultural dimension, while also producing a more centripetal, less polarized parliament.
\end{abstract}

Keywords: ideological congruence; ballot structure; expressive voting; electoral institutions; survey experiment

As commentators proclaim a 'crisis of democracy' in the face of falling turnout rates, declining partisanship, mainstream party convergence and the rise of populist parties, a growing literature explores the opportunities for democratic renewal to improve the quality of democracy (e.g. Font et al. 2018; Hendriks and Kay 2019). Left largely ignored, however, is the potential of adjusting ballot structures to improve the quality of democratic representation (but see Blumenau et al. 2017;

(C) The Authors 2019. Published by Government and Opposition Limited and Cambridge University Press. This is an Open Access article, distributed under the terms of the Creative Commons Attribution licence (http://creativecommons.org/licenses/by/4.0/), which permits unrestricted re-use, distribution, and reproduction in any medium, provided the original work is properly cited. 
on the potential of flexible and open-list ballots see Renwick and Pilet 2016). This is surprising as the ballot structure affects the core functioning of a representative democracy.

The quality of democracy depends in large part on whether a voter is able to vote in accordance with her preferences (Dahl 1956). Researchers have employed the yardstick of ideological congruence along which the similarity between the voters' and representatives' preferences can be gauged (see Golder and Stramski 2010 for an overview). Improving ideological congruence thus appears to be a straightforward way for strengthening the quality of democracy (Dahlberg and Holmberg 2014; Stecker and Tausendpfund 2016). As a higher number of parties makes it easier for citizens to vote in line with their preferences (Huber and Powell 1994; Laver and Sergenti 2012), one may want to adjust the institutional rules to create a large party system by increasing assembly size and district magnitude (Shugart and Taagepera 2018). Yet, permissive electoral rules that produce large party systems may come at the cost of greater ideological polarization in parliament (cf. Dalton 2008; Farrell 2011). More parties in parliament may hinder the formation of stable governments. Moreover, the link between government formation and a voter's choice is weaker in multiparty systems compared with systems with a higher party concentration (Ferland 2018).

We argue that there is an institutional characteristic of electoral systems other than party system size through which ideological congruence may be improved but which may maintain party system concentration: the extent to which the ballot structure allows voters to vote 'expressively'. This is the degree to which a voter may distribute his or her electoral strength over multiple options. For example, voters may rank-order candidates or split their ticket, as is the case in Ireland and Germany respectively. These types of expressive ballots allow voters to express their preferences more precisely. With simple categorical ballots, in contrast, a voter has to throw her entire electoral strength behind one party or candidate (Gallagher and Mitchell 2018; Rae 1971). To our knowledge, whether congruence increases under conditions of non-categorical - expressive - ballot structures has not explicitly been assessed in previous research. In addition, we argue that a ballot structure that allows expressive voting may have a centripetal effect on parliamentary composition as centrist parties are strengthened and party concentration is maintained.

The ballot structure we propose is the 'assembly ballot' (AB). It is a dividual ballot that asks voters to create their 'ideal parliament' by distributing all available seats across all parties they want to see represented in parliament. In combination with a proportional electoral formula and a low effective threshold, the $\mathrm{AB}$ will produce a parliament reflecting the aggregate of all voters' ideal assemblies. Positive-sum gains across multiple dimensions of representative democracy may be achieved with the $\mathrm{AB}$. Besides higher ideological congruence and a higher seat share for the centrist parties, the degree of party concentration is maintained as assembly size and district magnitude are unaffected. In addition, a more direct link between voters' choice and coalition governments can be established as voters' 'ideal parliaments' suggest their coalition preferences.

In this contribution, we assess whether the $\mathrm{AB}$ can increase the ideological correspondence between voters and representatives and what the effect of the $A B$ is on parliamentary composition. Studying counterfactual systems of representation can shed light on how electoral reform can affect political behaviour and parliamentary 
composition (see also Eggers and Lauderdale 2016). As such, it can also lay bare the strengths and weaknesses of the electoral systems in place.

We conducted a survey-based, vignette experiment on a panel of Dutch voters collected via the Dutch Vote Advice Application (VAA) Kieskompas (Election Compass, see Krouwel et al. 2012; Wall et al. 2014). The permissive electoral system in the Netherlands produces a high number of political parties - facilitating an ideologically congruent vote. The positive effect of the $\mathrm{AB}$ on voters' ideological congruence is therefore presumed to be least impactful in a political system like the Netherlands - making it a 'least-likely' crucial case (Gerring 2007: 116). We employed a randomized design in which respondents were either asked to cast their vote with a closed-list single-vote ballot - which is essentially how voters currently vote in Dutch democracy - or with the $\mathrm{AB}$. The $\mathrm{AB}$ allowed voters to allocate the 150 seats of the Dutch Tweede Kamer to 28 parties. We estimated the effects on ideological congruence on both the socioeconomic dimension and the cultural dimension.

Our findings show that, on average, congruence between a respondent's ideological self-placement and vote choice is significantly higher on the socioeconomic dimension and even more so on the cultural dimension among respondents 'voting' with the $\mathrm{AB}$ compared with respondents in the control group voting with a closed-list singlevote ballot. In a second step, we find that the parliament is considerably more centrist when constituted by the $\mathrm{AB}$ vote as opposed to the closed-list single-vote.

\section{Ideological congruence and representation}

Close correspondence between the policy preferences of the people and the policy decisions made by their representatives is often considered a necessary component of representation (Dahl 1956). To Hanna Pitkin (1967), such substantive representation takes precedence over formalistic, symbolic or descriptive forms of representation as it has a bearing on the actions taken by representatives. As Matt Golder and Benjamin Ferland (2018) note, empirical political scientists have operationalized substantive representation both as ideological congruence (Huber and Powell 1994) and as policy responsiveness (Page and Shapiro 1983). ${ }^{1}$ Whereas responsiveness refers to a dynamic relationship between change in public opinion and change in policy output (e.g. Hobolt and Klemmensen 2008; Soroka and Wlezien 2010), congruence refers to a static assessment of the correspondence of public preferences and policy positions adopted or policy measures taken at a certain point in time (Golder and Ferland 2018: 215).

Ideological congruence is often studied at the aggregate level. The proximity between the mean or median ideological position in the citizenry is examined at different geographic levels of aggregation on the one hand, and the position of a single representative actor, such as a member of Congress (Miller and Stokes 1963), the position of a political party (Belchior 2013), the position of a national government (Huber and Powell 1994; Powell and Vanberg 2000) or the position of the entire legislature (see also Dolný and Baboš 2015; Ezrow and Xezonakis 2011; Golder and Stramski 2010) on the other hand. As citizens hold preferences for multiple parties, a recent study has shown that assessing the extent to which government composition reflects the average party preferences of citizens holds great promise for studying the quality of representation at the aggregate level (Blais et al. 2017). 
Such aggregate-level measures of ideological congruence between citizens and representatives or governments, however, mask whether the ideological placement of individual citizens is congruent with the chosen representative or party. By contrast, the literature on individual-level congruence examines the ideological agreement between those represented and those representing on the individual voter level. Some studies examine the congruence between a voter's preference and the position of a median party, legislature or government (Kim 2009; Mayne and Hakhverdian 2017; Singh et al. 2011). Such measures of congruence, however, cannot assess whether or under what conditions an individual voter is ideologically congruent with the representative or party she or he has voted for. In this vein, Richard Lau and David Redlawsk (1997) examine the extent to which voters are able to 'vote correctly' - that is, their ability to choose a candidate who is closest to their ideological preferences and beliefs.

Congruence between a voter and the representative or party chosen can be thought of as the proximity between elector and elected in a spatial conception of the political space (Downs 1957). As a result, selecting the best candidate is not a binary question of 'correctness', but a matter of degree: to what extent do the ideological characteristics of the voter match the representative of the party voted for? In this respect, research has started to focus on the correspondence between continuous measures of voters' and representatives' ideological preferences (Golder and Stramski 2010) - focusing on the consequences of incongruence for abstention voting (Lefkofridi et al. 2014), the relationship between congruence and voters' satisfaction with democracy (Dahlberg and Holmberg 2014; Stecker and Tausendpfund 2016) or the effect of party identification and political sophistication on congruence (Boonen et al. 2017). To assess the consequences of ballot structures for the quality of representation we adopt this individual-level approach to congruence in this study.

\section{Electoral systems and individual-level congruence}

As the supply of political parties increases, the easier it becomes for voters to vote in line with their ideological preferences. The number of relevant parties a voter can choose from is largely determined by the 'permissiveness' of electoral institutions (Shugart and Taagepera 2018). Higher district magnitude and greater assembly size broaden voters' range of relevant choice as parties gain parliamentary representation more easily. As such, while very small district magnitude in single-member plurality (SMP) systems offers voters a relatively small number of relevant parties to choose from, proportional representation (PR) systems with high district magnitude produce ballots with a higher number of viable party choices. For example, Israel's and the Netherlands' de facto nationwide electoral districts - the district magnitude equals the assembly size - make these countries' electoral systems as permissive as is possible (Shugart and Taagepera 2018).

Yet, it has been prominently argued in the literature that the permissiveness of an electoral system comes at the cost of both greater ideological polarization and greater government instability (Dalton 2008). More permissive electoral systems are argued to have centrifugal tendencies as ideologically extreme parties are more likely to achieve parliamentary representation, while less permissive systems 
produce centripetal incentives (Cox 1990). Ideological polarization among parties, or average party extremism, is moreover associated with lower satisfaction with democracy (Ezrow and Xezonakis 2011). At the same time, it is argued that permissive electoral systems produce ideologically diverse governing coalitions which can inhibit effective government (Farrell 2011). The 2017 Dutch parliamentary election, in which 13 parties entered parliament and four parties were needed for a governing majority, is a case in point. Ideological diversity in government, moreover, negatively affects citizens' perceptions of government performance (Singh and Thornton 2016). Furthermore, in comparison to systems with a higher party concentration, the link between government formation and a vote choice is weaker in systems that require a multiplicity of coalition parties. Unsurprisingly, therefore, coalition governments with a higher number of parties have more difficulty in being responsive to their voters (Ferland 2018).

In sum, the literature suggests that an increase in parties due to permissive electoral rules comes with a trade-off. Whereas a large party system may improve the congruence between a voter and her vote, coalition government stability and responsiveness become weaker.

\section{Ballot structures and expressive voting}

We posit that there is another institutional characteristic of electoral systems that may improve voter-vote congruence: the ballot structure (Gallagher and Mitchell 2018). Ballot structures vary in their expressiveness. Expressiveness refers to the degree to which a voter may distribute his or her electoral strength over multiple options. Categorical ballots offer the smallest degree of expressiveness: the ballot forces a voter to throw her entire electoral strength behind one party or candidate (Rae 1971). That said, flexible and open-list categorical ballots do allow voters to express their preference for a specific candidate (André et al. 2012; Renwick and Pilet 2016). Ordinal ballots are more expressive as they allow a rank-ordering of parties or candidates. Dividual ballots allow voters to divide their votes among more than one party or candidate. For instance, with 'split-tickets' in mixed-member electoral systems, voters can vote for different parties with their two votes. In 'panachage' systems, moreover, voters may distribute a number of preference votes among candidates of more than one party (Gallagher and Mitchell 2018).

An open question in the literature is how voters distribute their electoral strength under non-categorical, expressive ballots. A straightforward expectation is that voters distribute their 'electoral strength' as they would vote under categorical ballots: They aim to minimize the distance between their own preferences and the preferences as reflected by their vote choice. In other words, voters opt for the choice that is located closest to them on a hypothetical political landscape (Downs 1957). Jack Blumenau et al. (2017), for instance, found that voters voting under open-list systems are willing to abandon their party of choice to vote for an opposing party's candidate standing closer to their own preferences. In addition, recent research indicates that in mixed-member systems voters may use their two votes to express a more nuanced electoral choice (Plescia 2017; Riera and Bol 2017). These observations strongly suggest that voters vote more expressively when so enabled by the electoral rulebook. 


\section{The assembly ballot}

Collective decisions affecting self-determination should include those affected, the argument goes (Urbinati and Warren 2008). In multiparty systems, collective decisions are typically made through deliberations between multiple parties in parliament. As the composition of parliament determines its collective decisions, one may posit that voters must have a strong as possible verdict on parliamentary composition. Yet, a categorical ballot vote does not allow voters to express their preferred parliamentary composition.

While we do not wish to make a conclusive statement on which institutional mechanisms should be employed to translate the views of the individuals into a collective choice, we suggest a ballot that allows voters to customize their preferred parliamentary composition: the assembly ballot $(\mathrm{AB})$. The $\mathrm{AB}$ asks voters to create their 'ideal parliament' by distributing all available seats across all the participating parties they want to see represented in parliament. For instance, one might give two parties half of the seats each if one agrees with both equally, or give one party two-thirds of the seats and distribute the remaining seats over four different parties. In combination with a proportional electoral formula and a low effective threshold, the $\mathrm{AB}$ will produce a parliament that reflects the aggregate of all voters' 'ideal' assemblies. As a result, the final parliamentary composition as well as the potential coalition governments reflect the one most voters agree on the most. The $A B$ streamlines the process of representation as it establishes an explicit link between voter and parliament, voter and coalition government, and thus ultimately between voter and policy.

Also, while the accurate reflection of the main divisions and interests of the citizens in parliament are conceived of as the 'proportional ideal' (Pitkin 1967), it is important to recognize that individuals might have political interests and preferences which do not neatly align with a single political party (Blais et al. 2017; van der Eijk et al. 2006). Dutch voters in particular have been found to consider an increasing number of parties for the elections (van der Meer 2017). Indeed, as the $\mathrm{AB}$ allows the expression of pluralistic preferences, it may be a more suitable voting device in times of decreasing partisanship and volatility (André et al. 2015; Dassonneville 2018). If voters do not have pluralistic political preferences or choose not to express them, however, all seats may be allocated to a single party - as in a categorical ballot. The $\mathrm{AB}$ does not force voters to vote differently, it merely enables them to do so. The number of ideal parliaments that can potentially be made by a voter - the number of ways a voter's electoral strength can be distributed over the options - is extremely high. For instance, an $A B$ in a system with 150 seats to divide between 15 parties results in roughly 65 quintillion unique possible votes or seat allocations. $^{2}$

We expect voters to distribute their electoral strength around their own ideological stance - performing an 'ideological balancing act'. If there is no perfect match between a voter's own position and a party, the voter may balance out the political positions she thinks the parties have by attributing certain seat shares to certain parties to match her own political position to the highest possible degree. Our expectation is bolstered by considerations regarding strategic and expressive voting. Strategic voting generally occurs when the voter anticipates the logic of 
seat allocation. As André Blais et al. (2012) argue, strategic voting is less likely when a vote will not be 'wasted'. As the $\mathrm{AB}$ aggregates all the votes to an assembly composition there is virtually no post-electoral distortion ('waste') of vote shares to the seat shares. Due to such low incentives for strategic voting, voters are more geared towards 'expressive voting'. We posit the following:

Hypothesis: Voter-vote congruence is higher for a respondent using the 'assembly ballot' than for a respondent using the 'closed-list ballot'.

Ideological congruence between a voter and the political representatives she chooses is often measured on the general left-right dimension (Boonen et al. 2017; Dahlberg and Holmberg 2014; Lefkofridi et al. 2014). We expect the assembly ballot to affect congruence on the economic dimension as well as on the cultural dimension - a dimension often disregarded in congruence studies (but see Laver and Sergenti 2012). In recent years, the increasing importance of this cultural dimension in party politics has been widely documented in the literature (Hooghe and Marks 2009; Kriesi et al. 2008). Both the electoral success of parties mobilizing on cultural issues and the fact that mainstream parties often react programmatically to such challengers by shifting their positions on cultural issues (Meguid 2005) strongly suggest that mainstream parties cannot satisfy voters' political demand for less centrist ideological positions. Using the $A B$, then, voters will also be able to allocate votes to parties which adopt clearer positions on the cultural issue.

If voters indeed perform the abovementioned balancing act, both moderate leftand right-leaning voters are expected to attribute a share of seats to these left- or right-wing parties but also to centrist parties. So-called 'centrist voters', on the other hand, already attribute a considerable number of seats to the middle parties and will presumably be less inclined to attribute seats to non-centrist parties. As such, a more centripetal assembly composition may be expected due to the increased seat share for middle parties that comes at the cost of the non-centrist parties' seat shares - and thereby avoiding strong parliamentary polarization (Dalton 2008).

\section{Data and method}

\section{Data: case selection and online survey experiment}

Due to the permissiveness of its political system, as many as 28 parties competed in the 2017 Dutch parliamentary elections. We therefore presume that Dutch voters are able to find a closely located party with relative ease and are thus least likely to show an improvement in their congruence scores when voting with the $\mathrm{AB}$. The Dutch case represents a confirmatory 'least-likely' crucial case (see Gerring 2007: 116). If the hypothesis is confirmed it is very plausible that the $A B$ may yield similar or starker results elsewhere.

Data were collected through a survey-based, vignette experiment on a panel of Dutch voters collected via the Dutch VAA Kieskompas (Krouwel et al. 2012; Wall et al. 2014). Employing a randomized design, respondents were either asked 
to cast their vote with a closed-list single-vote ballot, akin to how Dutch voters currently vote (Jacobs 2018), or with the $\mathrm{AB}$, which allowed voters to allocate the 150 seats of the Dutch Tweede Kamer to all participating parties. ${ }^{3}$ Panel respondents were recruited after previously visiting the VAA Kieskompas in national and local elections. Our survey was fielded in the weeks leading up to the 2017 parliamentary elections, and 16,688 respondents participated in the experiment. ${ }^{4}$

Online opt-in surveys generate non-probability samples (van de Pol et al. 2014) that may lead to biased estimates (Bethlehem 2010; Hooghe and Teepe 2007). Despite the issue of generalizability, the benefits of opt-in web surveys are the sheer size of the panel, the ability to reach voters of fringe and radical parties and the willingness of respondents to answer many questions more accurately compared with traditional probability surveys (Kreuter et al. 2008; Sakshaug et al. 2010), resulting in smaller measurement error. Furthermore, in an experiment these issues of non-randomness are alleviated as we can isolate and manipulate the causal stimuli (the ballot) and as such make an unequivocal causal inference (Iyengar 2002).

\section{Operationalization: voter-vote congruence}

Voter-vote congruence is calculated as the absolute difference between a respondent's self-placement and her vote choice. Ideological self-placement is measured by asking respondents to place themselves on an 11-point scale (1-11) for both the socioeconomic dimension and the cultural dimension. ${ }^{5}$ Vote choice is either the placement of the party voted for (Boonen et al. 2017; Lefkofridi et al. 2014) or the placement of the weighted average of the multiple parties voted for within the $A B$ format. Party placement is based on placement by academic experts, based on evidence from party platforms and other authoritative sources of party positions on issues on an 11-point scale (0-10) (for the method, see Garzia and Marschall 2012; Krouwel and Elfrinkhof 2014). While political parties were also given the opportunity to provide a self-placement on all the issues constituting the two ideological dimensions, positions are only accepted when they can be corroborated by text snippets from formal documentation from election manifestos, websites, campaign material or speeches and media appearances by party leaders that justify that position (Krouwel et al. 2012; Trechsel and Mair 2011). Parties' ideological positions are depicted in Table Al of the online Appendix. Placements were assessed for parties that already had seats or consistently polled above two seats. Parties not meeting this threshold were excluded from the analysis.

Any vote choice is translated as a position on both issue dimensions indicated with the integral $A_{j}$ in Equation 1 ( $A$ stands for Assembly). The portion of a vote $(P)$ given to party $i$ by voter $j$ is indicated with $P_{i j}$. For respondents voting with a regular ballot the portion $P$ of the vote was 1 for one party and 0 for the others. However, if a respondent voted with an $\mathrm{AB}$, the score of her $A_{j}$ on both dimensions was the sum of the portion $P$ a particular party $(i)$ had in this voter's ( $j$ ) ideal parliament (anywhere between 0 and 1 ) multiplied by the party's score $S_{i}$.

$$
A_{j}=\sum_{i=1}^{n} P_{i j} S_{i}
$$


To calculate voter-vote congruence, the absolute distance between the voter's $A_{j}$ and her self-placement is calculated. The self-placement score $S$ of respondent $j$ is indicated with the integral $S_{j}$ in Equation 2. To ease interpretation, we multiply by -1 . Hence, if the distance between respondent $j$ 's vote score and self-placement goes down, her congruence score goes up (see Equation 2).

$$
C_{j}=-\min \left|A_{j}-S_{j}\right|
$$

(Equation 2)

The maximum (ideal) score on the congruence scale is 0 . The minimum (leastideal) score is around -9 . This is as much as a respondent can vote 'wrongly', for example by attributing herself a score of 10 on the left-right scale but voting (entirely) for the left-wing Socialistische Partij (Socialist Party, SP), which has a score of 0.4 .

We calculate congruence scores for both the economic and cultural dimensions (see Germann et al. 2015; Krouwel 2012; Otjes and Louwerse 2014). A twodimensional space is better capable of capturing issue competition between parties in European multiparty system than the Downsian model with a single left-right axis (Downs 1957). While the economic left-right dimension is still very relevant, this dimension is in many contexts cross-cut by a cultural dimension. Also called the new politics dimension, this cultural dimension pertains to attitudes towards morality, immigration and national identity (Hooghe and Marks 2018; Hooghe et al. 2002). The descriptive statistics of all variables can be found in Table A2 in the online Appendix.

\section{Estimation method}

We use OLS regression analysis to examine the impact of the assembly ballot on voter-vote congruence. We calculate separate models for ideological congruence on the economic and cultural dimensions. The main independent variable is a binary variable which denotes either voting with the assembly ballot or a 'regular' vote by a closed-list ballot as is de facto the case in real Dutch elections. In other words, we investigate whether $C_{j}$ on the left-right dimension, $C_{j(\text { (economic) }}$, or on the cultural dimension $C_{j(\text { cultural })}$ will be significantly improved by the $A B^{6}{ }^{6}$

\section{Findings}

Before we can assess the effect of the $\mathrm{AB}$ on voter-vote congruence and, subsequently, on parliamentary composition, it is important to establish the extent to which respondents actually used the $A B$ to split up their votes. Figure 1 depicts the seat proportion a respondent allocated to the largest party when using the $\mathrm{AB}^{7}$ On average, voters gave the largest party a proportion of $0.33(33 \%)$ of the seats, indicating that the remaining $67 \%$ were distributed over at least two other parties. A remarkable $89.6 \%$ of the respondents 'voting' with the $A B$ gave no single party a majority of the seats. Most $\mathrm{AB}$ respondents elected between 4 and 10 parties (see Figure $\mathrm{A} 1$ in the online Appendix). This suggests that voters recognize the added value of a more expressive ballot. 


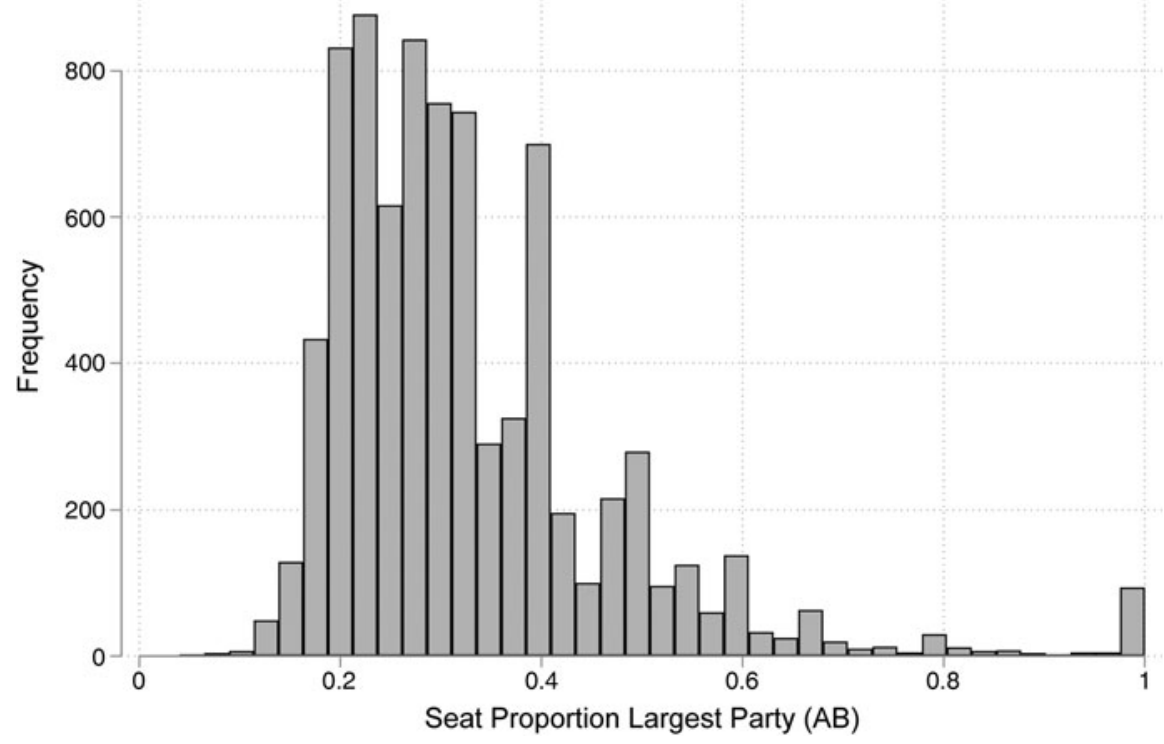

Figure 1: Histogram of the Seat Proportion Voters Allocated to Their Largest Party in the AB

\section{The assembly ballot's effect on ideological congruence}

Now we turn to the question of whether and how the $\mathrm{AB}$ affects voter-vote congruence vis-à-vis the closed-list ballot. Figure 2 shows the results of the survey experiment assessing the effect of ballot type on ideological congruence. Specifically, Figure 2 depicts the predictive margins of ballot type of ideological congruence based on a simple bivariate OLS regression analysis for the economic dimension (left panel) and the cultural dimension (right panel). The values on the y-axis denote the predicted congruence score. The estimates are based on the models in Table A3 in the online Appendix. The results show that, on average, the $A B$ improves respondents' ideological congruence for both dimensions, as our hypothesis posited, and that these effects are statistically significant. While ideological congruence is consistently higher on the economic dimension for both ballot types, the average effect of the $\mathrm{AB}$ is much more pronounced for the cultural dimension. Given that the congruence variable ranges from approximately -9 to 0 , the results point to a substantive improvement in congruence for the $A B$.

Yet, are all respondents equally likely to improve their congruence? The $A B$ is expected to improve voter-vote congruence particularly for voters for whom political supply is lacking. If a voter places herself at 5 and there are two parties with scores of 3 and 7 respectively, the $A B$ would have much added value as a voter can give both parties half the seats to get a score of 5 . For a voter whose preferences perfectly align with one party, attributing seats across multiple parties logically worsens the congruence score. Therefore, we further explore whether the effect of ballot type is moderated by a voter's distance to the closest party. Moreover, ideologically extreme voters have less chance of improving their congruence score with the $\mathrm{AB}$ as the lack of political supply makes them less able to balance their vote. Therefore we 

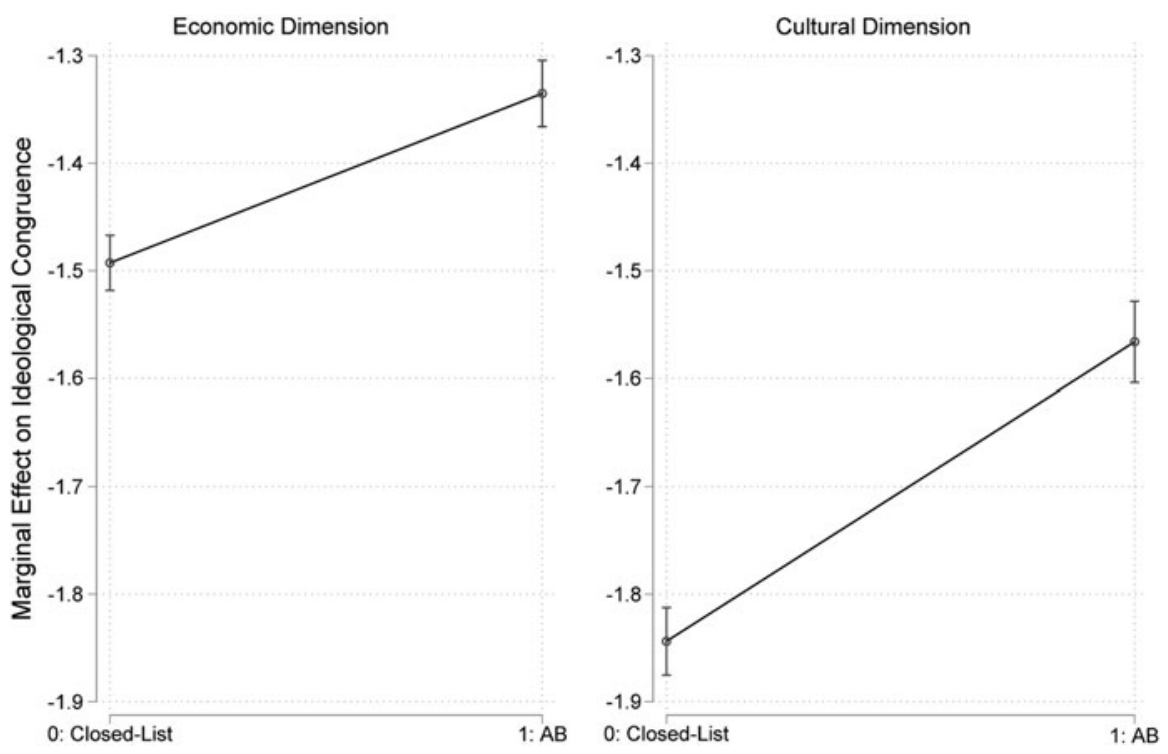

Figure 2: Predictive Margins Plot of Ballot Type on Ideological Congruence per Ideological Dimension

also explore the moderating effect of self-placement on the economic and cultural dimensions on the relationship between ballot type and congruence. ${ }^{8}$

First, we measure the interaction effect between the ballot type and a respondent's distance to the closest party (see Table A5 in the online Appendix). We include a quadratic term of distance to the closest party, as the Ramsey Regression Equation Specification Error Test suggested that the relationship between a respondent's distance to the closest party and ideological self-placement is not linear for both dimensions. Plotting the predictive margins of this interaction, Figure 3 shows that $\mathrm{AB}$ respondents almost always obtain a higher congruence score than closed-list counterparts with similar distance to the most closely located party on both the economic (left panel) and cultural dimension (right panel). Only if a voter has a 'perfect match' on the economic dimension is the difference between $\mathrm{AB}$ and closed-list voting not statistically significant. Particularly for the cultural dimension, the difference between ballot types becomes more substantial the further a respondent is ideologically removed from the most closely located party. In short, voter-vote congruence is higher for $\mathrm{AB}$ respondents compared with closed-list ballot respondents when distance between their own ideological position and the closest located party is not 0 .

Second, how does the ideological self-placement of respondents affect the effect of ballot type on ideological congruence? Figure 4 shows a predictive margins plot based on the interaction between ballot type and ideological self-placement for both dimensions. The plots are based on the models in Table A6 in the online Appendix. A quadratic term of self-placement was included as the relationship with the dependent variables appeared to be non-linear. The figure shows that the positive effect of the $\mathrm{AB}$ is limited to centrist voters. On both the economic and cultural 

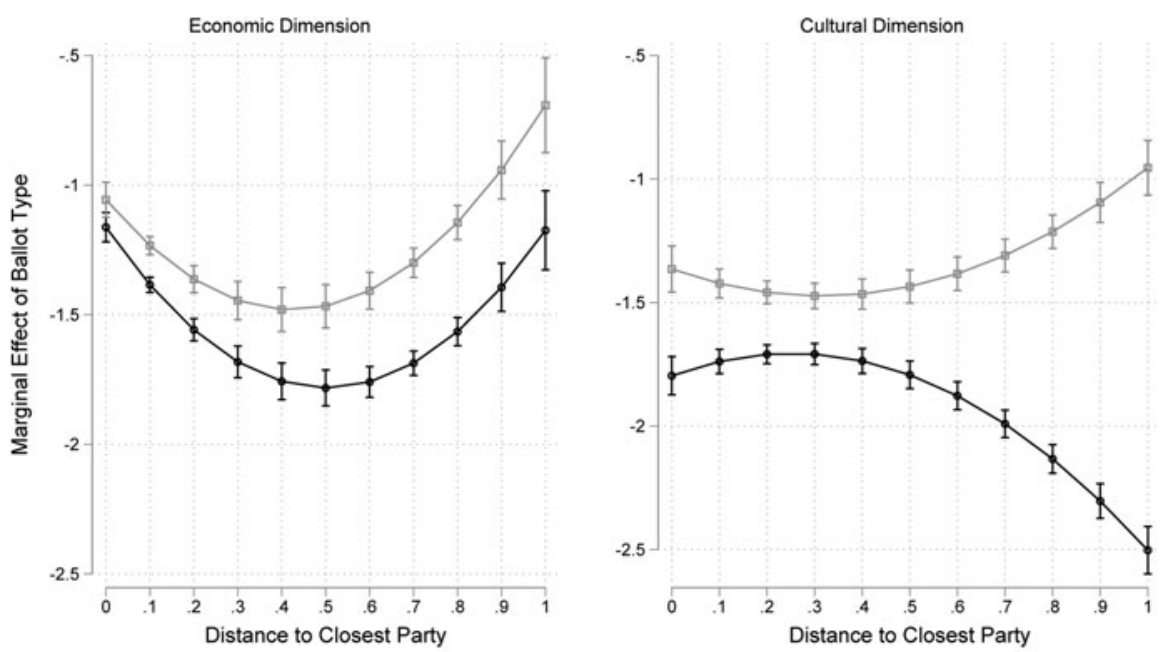

$\rightarrow$ 0: Closed-List

$\rightarrow$ 1: $A B$

Figure 3: Predictive Margins Plot of Ballot Type on Ideological Congruence by the Distance to Closest Party per Dimension
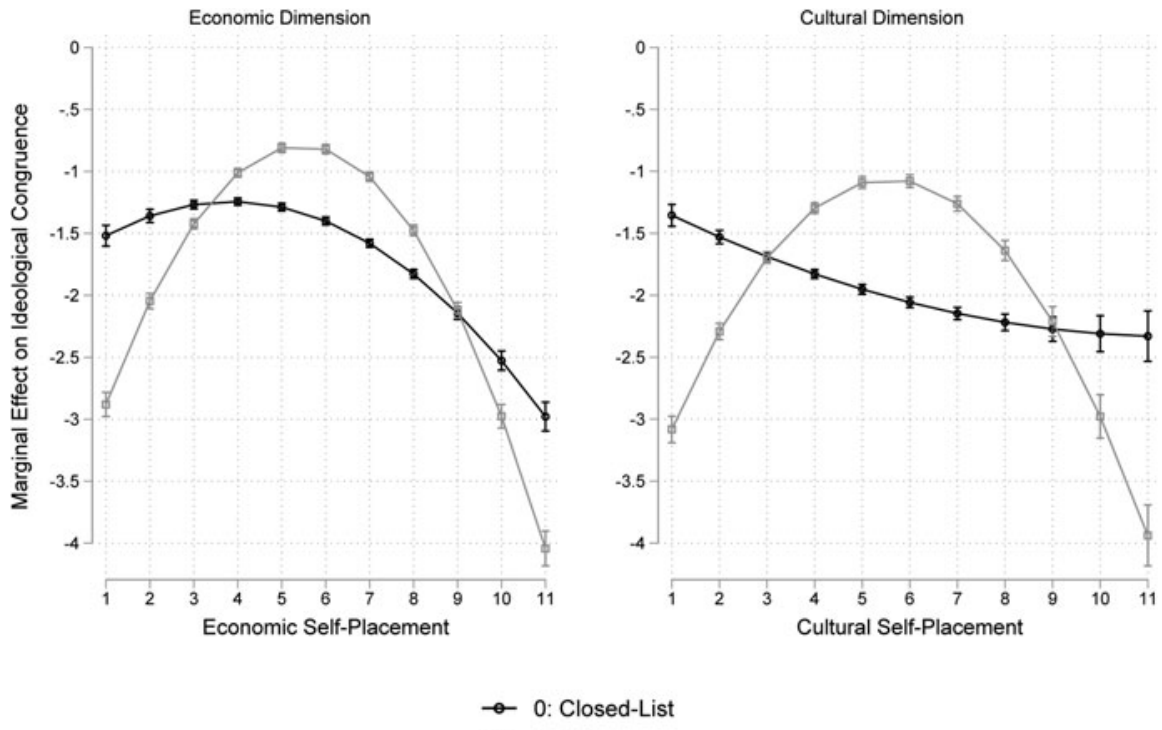

$\because-1: A B$

Figure 4: Predictive Margins Plot of Ballot Type on Ideological Congruence by Respondents' Self-Placement per Dimension 
dimensions, centrist respondents (4-8) obtain higher congruence scores when they vote with an $\mathrm{AB}$, whereas respondents with extreme, non-centrist positions (1-3 and 10-11) obtain higher congruence scores when voting with the regular closedlist ballot. This is unsurprising. As centrist respondents have parties on both sides, they are better able to balance their vote to obtain a higher congruence score. Non-centrist voters are best represented by parties with similarly extreme positions. If these respondents do choose to attribute seats to other parties with the $A B$, they select parties that are logically more distant than the parties they would opt for under the closed-list system.

\section{The AB's effect on parliamentary composition}

We now turn to the question of the effects of the $\mathrm{AB}$ for parliamentary composition and polarization within parliament. We have established that the AB can substantially improve ideological congruence between voters and their selected representatives. In particular, congruence scores for centrist respondents are improved. Furthermore, we found that extremist voters obtained worse congruence scores, which implies a more centrist vote choice. Both of these mechanisms should contribute to a more centrist parliamentary composition. In order to assess descriptively the consequences of the $\mathrm{AB}$ for the composition of the parliament, Figure 5 presents the counterfactual electoral results produced by respondents voting with a closed-list ballot (left graph) and with the assembly ballot (right graph).

Overall, the parties indeed converge in terms of their vote shares. The average party's size remains similar under both systems $(7.4-7.5 \%$ of the vote share) but the standard deviation in percentage of the vote for the 13 parties that make the electoral threshold decreases from 6 percentage points to 5.6 percentage points. The vote shares thus appear to be distributed more evenly across all parties. The seat shares of parties with regular governing experience (Christen-Democratisch Appèl (Christian Democratic Appeal, CDA), Partij van de Arbeid (Labour Party, PvdA) and Volkspartij voor Vrijheid en Democratie (People's Party for Freedom and Democracy, VVD)) in particular are closer to one another in the AB system. But, each of these parties secure higher seat shares than under the closed-list ballot. Moreover, the figure shows that the vote share for GroenLinks (GreenLeft) - a left-wing and culturally progressive party without governing experience - decreases quite substantively under the $A B$. Under the $A B$, voters who would otherwise have fully supported GroenLinks appear to attribute a certain number of seats to parties that are in the same left-wing 'choice-set' (van der Eijk et al. 2006), such as the PvdA and SP - two parties that indeed grow under the AB.

The mean position of $\mathrm{AB}$ votes on the left-right dimension is 4.37 on a 0-10 scale with a standard deviation of 1.33 . ${ }^{9}$ The mean of closed-list votes' left-right position is $4.13(\mathrm{SD}=2.36)$. On the cultural dimension, the mean of $\mathrm{AB}$ votes $(5.76, \mathrm{SD}=1.45)$ is also closer to the centre when compared with closed-list votes $($ mean $=6.09 ; \mathrm{SD}=2.60)$. For both dimensions, t-tests showed this difference to be statistically significant. That the means are closer to the centre and the overall Assembly Scores less dispersed suggests a centripetal effect of the AB ballot. 

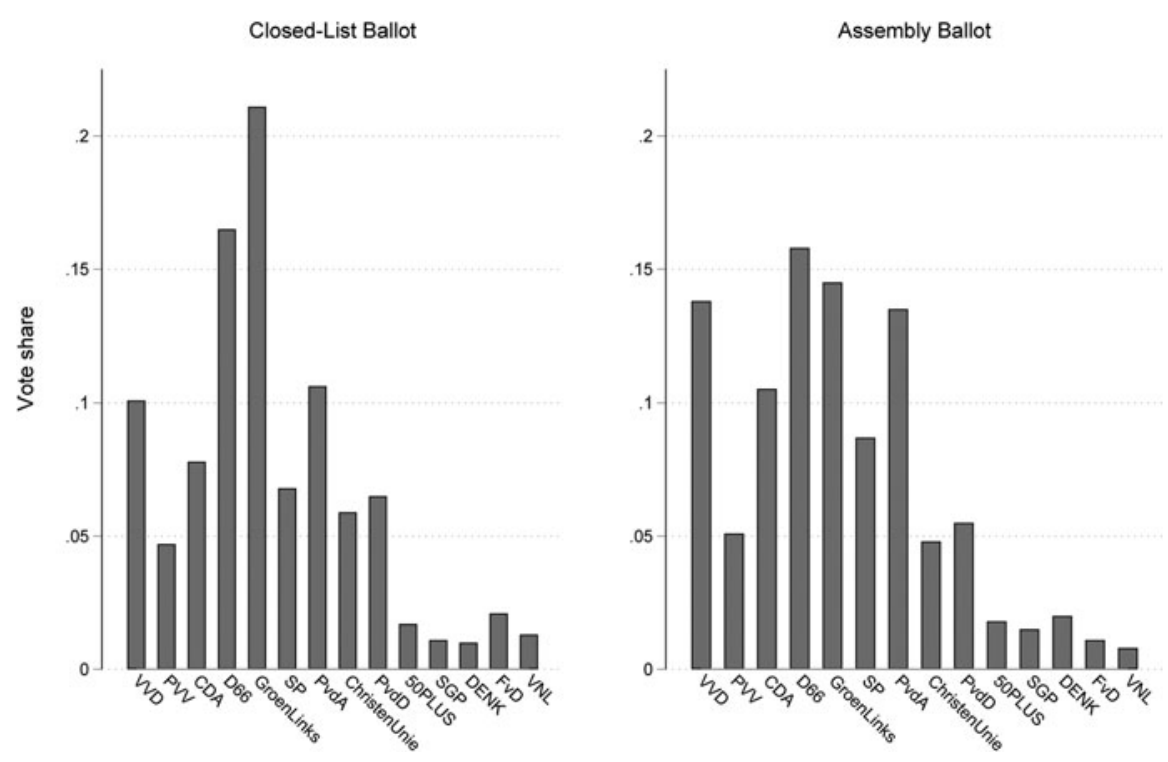

Figure 5: Bar Graph of Aggregate Results from the Closed-List Vote and the AB Vote

\section{Conclusion}

The composition of parliament determines its activities. If voters can shape their own 'ideal parliament', a more explicit link between voter and assembly, coalition, and ultimately policy may be established. We designed the assembly ballot (AB) with which voters can choose more expressively what the composition of parliament should look like by distributing all available seats across all participating parties. We expected a higher degree of congruence between a respondent and her vote when voting with the $\mathrm{AB}$. If voters indeed perform this ideological balancing act, we expect that moderate left and moderate right voters will allocate some of their seats to centrist parties to improve congruence, whilst centrist voters are less inclined to contribute seats to non-centrist parties. Thus, we expected the $\mathrm{AB}$ to have a centripetal effect - producing a more centrist parliament.

On the basis of a randomized survey experiment on a panel of Dutch voters using Kieskompas data, we found that the respondents 'voting' with an $A B$ improved their voter-vote congruence, on average, compared with respondents voting with a closed-list ballot. This effect, however, is limited to centrist voters only. Ideologically more extreme voters could logically not improve their congruence with the $\mathrm{AB}$. Moreover, we found that the less proximate the closest party was, the better the improvement in congruence for $\mathrm{AB}$ respondents. What is more, the $A B$ had a more substantive positive effect on the cultural dimension than on the economic dimension.

The larger $\mathrm{AB}$ effect on cultural congruence may indicate that the Dutch party system already has much to offer on the economic dimension. In terms of cultural issues, however, voters' political demands are not sufficiently met. Here, the $A B$ offers voters the opportunity to give a more nuanced position. The political supply 
of 'conservative' cultural politics possibly explains the discrepancy between the closed-list ballot and the $\mathrm{AB}$ on the cultural dimension. Indeed, parliamentary composition under the $\mathrm{AB}$ ballot is slightly more centrist on the cultural dimension than the closed ballot. While Dutch voters are likely to be hesitant to vote for a radical right party like the PVV in a closed-list ballot, their hunger for a more culturally conservative parliament can be stilled with the $\mathrm{AB}$, with which just a portion of the vote may be attributed to such parties.

With respect to the effects on parliamentary composition, the descriptive analysis also suggests the $A B$ has a centripetal effect. While electoral systems' permissiveness is usually associated with increased ideological polarization and greater government instability (Farrell 2011), the evidence tentatively suggests that a permissive system combined with an $\mathrm{AB}$ produces a parliament in which centrist forces are buttressed. This suggests that the $\mathrm{AB}$, in combination with a proportional electoral formula, maximizes voter expression and rewards parties to be ideologically distinctive without making the composition of parliament more fragmented and without empowering fringe forces. This is good news as a more centrist parliament may be associated with greater satisfaction with democracy (Ezrow and Xezonakis 2011). And while less polarization leads to weaker partisan attachments (Lupu 2015), it probably dampens ideological diversity in government, which negatively affects citizens' perceptions of government performance (Singh and Thornton 2016).

Yet, how would party strategy be affected by the $A B$ ? While the $A B$ produces a more centrist parliament, its main premise is that it rewards parties' (ideological) distinctiveness. Since voters' AB votes are probably similar across elections, this should dampen seat volatility and decrease the likelihood of high seat losses. One may posit that this should make parties less risk-averse - producing a more diverse palette of policy choices.

Counterfactual systems of representation illuminate the potential of electoral institutional reform and democratic renewal for the quality of representation (Blumenau et al. 2017; Cameron et al. 1996; Eggers and Lauderdale 2016). That said, one should keep in mind that the data in this study are based on an online opt-in survey which produces non-probability samples. Also, the results were generated in a counterfactual setting and we cannot be confident that any institution would function in the same way under conditions different from those under which it is observed (Przeworski 2004). As the literature on the psychological effects of electoral rules also notes (Blais et al. 2012), it is possible that subjects behave differently in an experimental electoral context from the way they behave in reality. That said, an immediate implication of these findings is that voters would use additional tools for the electoral expression of their preferences - if given to them.

Future research could further examine the effects of the ballot structure on ideological congruence in existing settings in which 'dividual' or panachage ballots are used, such as in El Salvador, Honduras and Luxembourg. In addition, there are a number of natural experiments one might exploit to disentangle the effect of the ballot structure on legislative composition. In Germany, the 'dividual' panachage ballot is used in municipal elections in some federal states and not in others, and in France it is only used in municipal elections in communes with fewer than 1,000 inhabitants. Moreover, in a number of countries one can leverage the 
fact that a 'dividual' ballot system existed and was subsequently discontinued (Austria, Belgium and Switzerland) or came to effect recently (El Salvador and Honduras). Lastly, future research should make an effort to ascertain whether seat volatility is indeed lower under systems with non-categorical ballots - as the votes cast are likely to be similar across elections.

Supplementary information. To view the supplementary material for this article, please visit https:/doi. org/10.1017/gov.2019.30

Acknowledgements. This research was previously presented at the 2018 Politicologenetmaal (24-hour Political Science Conference) jointly organized by the Dutch Political Science Association (NKWP) and the Flemish Association for Political Science (VPW). We particularly thank Wouter van der Brug, Josep Maria Comellas, Jan Kleinnijenhuis, Simon Otjes and Stefaan Walgrave for their helpful feedback. Special thanks to Yordan Kutiyski for his assistance with the data collection and to Giuseppe Carere. We also thank the three anonymous referees whose feedback has greatly improved this article.

\section{Notes}

1 Not all scholars subscribe to the idea that citizens' substantive policy positions guide their vote choice, however. Lenz (2012), for instance, argues that voters are cued by politicians' policy positions rather than holding politicians accountable and compelling them to follow their policy preferences (i.e. the logical opposite of responsiveness).

2 The short scale of this number is $65 \times 10^{18}$, calculated on the basis of the combination: $\frac{(150+15-1) \text { ! }}{150 ! 14 !}$

3 In the survey experiment, the $\mathrm{AB}$ is compared with a closed-list single-vote ballot PR system. In reality, the Dutch electoral system is a flexible list, 150-seat, single electoral district with no formal electoral threshold (Jacobs 2018).

4 The design of the experiment's questions can be found in online Appendix 2.

5 In keeping with other studies (Boonen et al. 2017; Dahlberg and Holmberg 2014; Lefkofridi et al. 2014; Stecker and Tausendpfund 2016) and the Comparative Study of Electoral Systems (2018) modules, the ideological self-placement question was asked in the same questionnaire and after the question in which respondents indicate voting behaviour. Replication analysis with a congruence measure calculated on the basis of left-right self-placement data from a previous wave shows the same substantive results. Replication analysis available upon request.

6 Since the substantive areas of interest are randomized, it is not necessary to control for individual-level variables pertaining to demographics or preferences. However, as their inclusion reduces the unexplained within-group variation in the dependent variable - thus including it increases the power for detecting treatment effects - we also report the analyses with control variables in Table A4 in the online Appendix.

7 Figures in this article are produced using graphing schemes created by Bischof (2017).

8 The descriptive statistics of these variables can also be found in Table A2 in the online Appendix.

9 All voters who voted for a party (one seat or more with $\mathrm{AB}$ or closed list) that the Kieskompas team did not assess scores for - because they were not represented in parliament or polled below two seats - were excluded from the analysis.

\section{References}

André A, Wauters B and Pilet JB (2012) It's Not Only About Lists: Explaining Preference Voting in Belgium. Journal of Elections, Public Opinion and Parties 22(3), 293-313.

André A, Depauw S and Beyens S (2015) Party Loyalty and Electoral Dealignment. Party Politics 21(6), 970-981.

Belchior AM (2013) Explaining Left-Right Party Congruence Across European Party Systems: A Test of Micro-, Meso-, and Macro-Level Models. Comparative Political Studies 46(3), 352-386.

Bethlehem J (2010) Selection Bias in Web Surveys. International Statistical Review 78(2), 161-188.

Bischof D (2017) New Graphic Schemes for Stata: Plotplain and Plottig. Stata Journal 17(3), 748-759. 
Blais A et al. (2012) Assessing the Psychological and Mechanical Impact of Electoral Rules: A Quasi-Experiment. Electoral Studies 31(4), 829-837.

Blais A, Guntermann E, and Bodet MA (2017) Linking Party Preferences and the Composition of Government: A New Standard for Evaluating the Performance of Electoral Democracy. Political Science Research and Methods 5(2), 315-331.

Blumenau J et al. (2017) Open/Closed List and Party Choice: Experimental Evidence from the UK. British Journal of Political Science 47(4), 809-827.

Boonen J, Pedersen EF and Hooghe M (2017) The Effect of Political Sophistication and Party Identification on Voter-Party Congruence: A Comparative Analysis of 30 Countries. Journal of Elections, Public Opinion and Parties 27(3), 311-329.

Cameron C, Epstein D and O'Halloran S (1996) Do Majority-Minority Districts Maximize Substantive Black Representation in Congress? American Political Science Review 90(4), 794-812.

Comparative Study of Electoral Systems (2018). CSES Integrated Module Dataset (IMD), https://doi.org/ 10.7804/cses.imd.2018-12-04.

Cox GW (1990) Centripetal and Centrifugal Incentives in Electoral Systems. American Journal of Political Science 34(4), 903-935.

Dahl RA (1956) A Preface to Democratic Theory. Chicago: University of Chicago Press.

Dahlberg S and Holmberg S (2014) Democracy and Bureaucracy: How their Quality Matters for Popular Satisfaction. West European Politics 37(3), 515-537.

Dalton RJ (2008) The Quantity and the Quality of Party Systems. Comparative Political Studies 41(7), 899-920.

Dassonneville R (2018) Electoral Volatility and Parties' Ideological Responsiveness. European Journal of Political Research 57(4), 808-828.

Dolný B and Baboš P (2015) Voter-Representative Congruence in Europe: A Loss of Institutional Influence? West European Politics 38(6), 1274-1304.

Downs A (1957) An Economic Theory of Democracy. New York: Harper.

Eggers AC and Lauderdale BE (2016) Simulating Counterfactual Representation. Political Analysis 24(2), 281-290.

Ezrow L and Xezonakis G (2011) Citizen Satisfaction with Democracy and Parties' Policy Offerings. Comparative Political Studies 44(9), 1152-1178.

Farrell DM (2011) Electoral Systems: A Comparative Introduction. Basingstoke: Palgrave Macmillan.

Ferland B (2018) Government Responsiveness under Majoritarian and (within) Proportional Electoral Systems. Government and Opposition: An International Journal of Comparative Politics, published early online, December, https://doi.org/10.1017/gov.2018.47.

Font J et al. (2018) Cherry-Picking Participation: Explaining the Fate of Proposals from Participatory Processes. European Journal of Political Research 57(3), 615-636.

Gallagher M and Mitchell P (2018) Dimensions of Variation in Electoral Systems. In Herron ES, Pekkanen RJ and Shugart MS (eds), The Oxford Handbook of Electoral Systems. Oxford: Oxford University Press, pp. 23-40.

Garzia D and Marschall S (2012) Voting Advice Applications Under Review: The State of Research. International Journal of Electronic Governance 5(3/4), 203-222.

Germann M et al. (2015) Spatial Maps in Voting Advice Applications: The Case for Dynamic Scale Validation. Acta Politica 50(2), 214-238.

Gerring J (2007) Case Study Research: Principles and Practices. Cambridge: Cambridge University Press.

Golder M and Ferland B (2018) Electoral Systems and Citizen-Elite Ideological Congruence. In Herron ES, Pekkanen RJ and Shugart MS (eds), The Oxford Handbook of Electoral Systems. Oxford: Oxford University Press, pp. 213-246.

Golder M and Stramski J (2010) Ideological Congruence and Electoral Institutions. American Journal of Political Science 54(1), 90-106.

Hendriks CM and Kay A (2019) From 'Opening Up' to Democratic Renewal: Deepening Public Engagement in Legislative Committees. Government and Opposition: An International Journal of Comparative Politics 54(1), 25-51.

Hobolt SB and Klemmensen R (2008) Government Responsiveness and Political Competition in Comparative Perspective. Comparative Political Studies 41(3), 309-337. 
Hooghe L and Marks G (2009) A Postfunctionalist Theory of European Integration: From Permissive Consensus to Constraining Dissensus. British Journal of Political Science 39(01), 1-23.

Hooghe L and Marks G (2018) Cleavage Theory Meets Europe's Crises: Lipset, Rokkan, and the Transnational Cleavage. Journal of European Public Policy 25(1), 109-135.

Hooghe L, Marks G and Wilson CJ (2002) Does Left/Right Structure Party Positions on European Integration? Comparative Political Studies 35(8), 965-989.

Hooghe M and Teepe W (2007) Party Profiles on the Web: An Analysis of the Logfiles of Non-Partisan Interactive Political Internet Sites in the 2003 and 2004 Election Campaigns in Belgium. New Media and Society 9(6), 965-985.

Huber JD and Powell GBJ (1994) Congruence between Citizens and Policymakers in Two Visions of Liberal Democracy. World Politics 46(3), 291-326.

Iyengar S (2002) Experimental Designs for Political Communication: From Shopping Malls to the Internet. Paper presented at workshop in Mass Media Economics, Department of Political Science, London School of Economics, 25-26 June.

Jacobs K (2018) Electoral Systems in Context: The Netherlands. In Herron ES, Pekkanen RJ and Shugart MS (eds), The Oxford Handbook of Electoral Systems. Oxford: Oxford University Press, pp. 557-580.

Kim M (2009) Cross-National Analyses of Satisfaction with Democracy and Ideological Congruence. Journal of Elections, Public Opinion and Parties 19(1), 49-72.

Kreuter F, Presser S and Tourangeau R (2008) Social Desirability Bias in CATI, IVR, and Web Surveys: The Effects of Mode and Question Sensitivity. Public Opinion Quarterly 72(5), 847-865.

Kriesi H et al. (2008) Globalization and its Impact on National Spaces of Competition. In Kriesi $\mathrm{H}$ et al. (eds), West European Politics in the Age of Globalization. Cambridge: Cambridge University Press, pp. 3-22.

Krouwel A (2012) Party Transformations in European Democracies. New York: State University of New York Press.

Krouwel A and Elfrinkhof A (2014) Combining Strengths of Methods of Party Positioning to Counter their Weaknesses: The Development of a New Methodology to Calibrate Parties on Issues and Ideological Dimensions. Quality \& Quantity: International Journal of Methodology 48(3), 1455-1472.

Krouwel A, Vitiello T and Wall M (2012) The Practicalities of Issuing Vote Advice: A New Methodology for Profiling and Matching. Journal of Electronic Governance 5(3-4), 223-243.

Lau RR and Redlawsk DP (1997) Voting Correctly. American Political Science Review 91(3), 585-598.

Laver M and Sergenti E (2012) Party Competition: An Agent-Based Model. Princeton: Princeton University Press.

Lefkofridi Z, Giger N and Gallego A (2014) Electoral Participation in Pursuit of Policy Representation: Ideological Congruence and Voter Turnout. Journal of Elections, Public Opinion and Parties 24(3), 291-311.

Lenz GS (2012) Follow the Leader? How Voters Respond to Politicians' Policies and Performance. Chicago: University of Chicago Press.

Lupu N (2015) Party Polarization and Mass Partisanship: A Comparative Perspective. Political Behavior 37(2), 331-356.

Mayne Q and Hakhverdian A (2017) Ideological Congruence and Citizen Satisfaction: Evidence from 25 Advanced Democracies. Comparative Political Studies 50(6), 822-849.

Meguid BM (2005) Competition Between Unequals: The Role of Mainstream Party Strategy in Niche Party Success. American Political Science Review 99(3), 347-359.

Miller WE and Stokes DE (1963) Constituency Influence in Congress. American Political Science Review 57(1), 45-56.

Otjes S and Louwerse T (2014) Spatial Models in Voting Advice Applications. Electoral Studies 36, $263-271$.

Page BI and Shapiro RY (1983) Effects of Public Opinion on Policy. American Political Science Review 77 (1), 175-190.

Pitkin HF (1967) The Concept of Representation. Berkeley: University of California Press.

Plescia C (2017) On the Mismeasurement of Sincere and Strategic Voting in Mixed-Member Electoral Systems. Electoral Studies 48, 19-29.

Powell GBJ and Vanberg GS (2000) Election Laws, Disproportionality and Median Correspondence: Implications for Two Visions of Democracy. British Journal of Political Science 30(3), 383-411. 
Przeworski A (2004) Institutions Matter? Government and Opposition: An International Journal of Comparative Politics 39(4), 527-540.

Rae DW (1971) The Political Consequences of Electoral Laws. New Haven: Yale University Press.

Renwick A and Pilet J-B (2016) Faces on the Ballot: The Personalization of Electoral Systems in Europe. Oxford: Oxford University Press.

Riera P and Bol D (2017) Ticket-Splitting in Mixed-Member Systems: On the Importance of Seat Linkage between Electoral Tiers. West European Politics 40(3), 584-597.

Sakshaug JW, Yan T and Tourangeau R (2010) Nonresponse Error, Measurement Error, and Mode of Data Collection: Tradeoffs in a Multi-Mode Survey of Sensitive and Non-Sensitive Items. Public Opinion Quarterly 74(5), 907-933.

Shugart MS and Taagepera R (2018) Electoral System Effects on Party Systems. In Herron ES, Pekkanen RJ and Shugart MS (eds), The Oxford Handbook of Electoral Systems. Oxford: Oxford University Press, pp. 41-68.

Singh SP and Thornton JR (2016) Strange Bedfellows: Coalition Makeup and Perceptions of Democratic Performance Among Electoral Winners. Electoral Studies 42, 114-125.

Singh SP, Lago I and Blais A (2011) Winning and Competitiveness as Determinants of Political Support. Social Science Quarterly 92(3), 695-709.

Soroka SN and Wlezien C (2010) Degrees of Democracy: Politics, Public Opinion, and Policy. Cambridge: Cambridge University Press.

Stecker C and Tausendpfund M (2016) Multidimensional Government-Citizen Congruence and Satisfaction with Democracy. European Journal of Political Research 55(3), 492-511.

Trechsel AH and Mair P (2011) When Parties (Also) Position Themselves: An Introduction to the EU Profiler. Journal of Information Technology and Politics 8(1), 1-20.

Urbinati N and Warren ME (2008) The Concept of Representation in Contemporary Democratic Theory. Annual Review of Political Science 11(1), 387-412.

van de Pol J et al. (2014) Beyond Young, Highly Educated Males: A Typology of VAA Users. Journal of Information Technology and Politics 11, 397-411.

van der Eijk C et al. (2006) Rethinking the Dependent Variable in Voting Behavior: On the Measurement and Analysis of Electoral Utilities. Electoral Studies 25(3), 424-447.

van der Meer T (2017) De verkiezingen van 2017 in meerjarig perspectief. In van der Meer T, van der Kolk H and Rekker R (eds), Aanhoudend Wisselvallig: Nationaal Kiezersonderzoek 2017, pp. 10-21.

Wall M, Krouwel A and Vitiello T (2014) Do Voters Follow the Recommendations of Voter Advice Application Websites? A Study of the Effects of Kieskompas.nl on its Users' Vote Choices in the 2010 Dutch Legislative Elections. Party Politics 20(3), 416-428.

Cite this article: Ellenbroek V, Meijers MJ, Krouwel A (2021). Beyond the Dichotomous Vote: Can Expressive Ballots Increase Ideological Congruence and Decrease Parliamentary Polarization? Government and Opposition: An International Journal of Comparative Politics 56, 427-445. https:// doi.org/10.1017/gov.2019.30 